\title{
Modernization of Administration of Parking Tax Collection With Tapping Box as a Supervision and Compliance Function of Regional Taxpayers in Bekasi City
}

\author{
Mainita Hidayati ${ }^{1}$, Wuwuh Andayani ${ }^{2}$, Ratih Kumala ${ }^{3}$, \\ Agus Subagiyo ${ }^{4}$, Pebriana Arimbhi ${ }^{5}$ \\ ${ }^{12345}$ Institut Ilmu Sosial dan Manajemen Stiami, Jakarta, Indonesia \\ Correspondent: mainita.h@gmail.com ${ }^{1}$, wuhanku1112@gmail.com ${ }^{2}$, rhaty07@gmail.com ${ }^{3}$, \\ agussbagiyo@gmail.com ${ }^{4}$, pebriana.arimbhi@gmail.com ${ }^{5}$
}

$\begin{array}{ll}\text { Received } & \text { : August 08, } 2021 \\ \text { Accepted } & \text { : August 25, } 2021 \\ \text { Published } & \text { : October 31, } 2021\end{array}$

Citation: Hidayati, M., Andayani, W., Kumala, R., Subagiyo, A., Arimbhi, P. (2021). Modernization of Administration of Parking Tax Collection With Tapping Box as a Supervision and Compliance Function of Regional Taxpayers in Bekasi City. Ilomata International Journal of Tax \& Accounting 2(4),295-303.

https://doi.org/10.52728/ijtc.v2i4.367

\begin{abstract}
Tax modernization seems to be very necessary in the current digital era. This considers that taxes are one of the largest sources of tax revenue, both in the central and regional regions. This study focused on the scope of the Regions, one of the sources of Regional Tax is parking tax. The phenomenon that occurred in this study was the low acceptance of Parking Tax on Regional Taxes. In order to increase regional income and prevent any leakage of funds, the Bekasi City Regional Revenue Agency has installed a data management application in several places of business, namely Tapping Box. Tapping Box is a machine or transaction recording device that can record all transaction data that occurs and sends it to the Bekasi City Regional Revenue Agency server through the Global System for Mobile network (GSM). The purpose of installing the Tapping Box is as a means of monitoring and testing taxpayer compliance that displays the financial reports of transaction in a transparent and accountable way. This study used a descriptive type of research with a qualitative approach. Also, the data was analyzed by using qualitative method. The results of this study indicated that parking tax supervision has not gone well because there were still some taxpayers who have not installed the Tapping Box. The result of this Tapping Box installation is that the realization of parking tax receipts has not reached the set target, but the parking tax revenues have increased comparing to those in the previous year. Moreover, if the installation of the Tapping Box is evenly distributed, the parking tax revenue will be maximized.
\end{abstract}

Keywords: Modernization, Tapping Box, Local Tax

\section{INTRODUCTION}

For a country, taxes are a source of income used for infrastructure development, employee costs, paying foreign debts, and so on. Taxpayer compliance determines the achievement of tax revenue targets in a country. (Bird \& Zolt, 2005; Tscharaktschiew \& Reimann, 2021) In the era of regional autonomy, one of the sources of income for the region or local revenue comes from local taxes or 


\section{Modernization of Administration of Parking Tax Collection With Tapping Box as a Supervision and Compliance Function of Regional Taxpayers in Bekasi City \\ Hidayati, Andayani, Kumala, Subagiyo, Arimbhi}

levies. One source of income for the region comes from levies or parking taxes. Parking tax is a tax levied by the region or private parties who provide parking spaces in an area. (Feitelson \& Rotem, 2004; Gragera et al., 2021). So far, parking tax revenues in the regions have not been effective in increasing local revenue even though the potential for parking tax revenues is quite large. This indicates that there are problems in the effectiveness of parking tax receipts, including not achieving the target or realization of parking tax receipts (Ostermeijer et al., 2021; Parmar et al., 2021)

Nowadays, the modernization of tax administration carried out by the government is certainly not only to pursue and reach the optimization of tax collection, but there is another side that is also important to do together in order to lead to a change in the taxation paradigm. (Mardiasmo, 2016). Tax provisions, procedures, and activities are also continuously directed to improve services, so they become business friendly for the community, especially for business people (Pandiangan, 2008). Modernization of Tax Administration affects the Quality of Tax Services because it is one of the important steps taken by the government as a tangible manifestation of concern for the

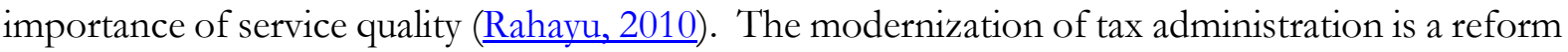
process of reformation in the field of tax administration that is carried out comprehensively. This includes aspects of information technology, namely software, hardware, and human resources with the aim of achieving a level of tax compliance and achieving high productivity of tax officials. Thus, it is expected this can reduce the practice of Corruption, Collusion, and Nepotism (KKN) (Sadhani, 2012). Furthermore, the modernization of Tax Administration can be interpreted in terms of a more sophisticated Information Technology (IT) application (Rosdiana \& Irianto, 2012).

The phenomenon occurred in this study is the low revenue of parking taxes on regional taxes. This is due to the lack of supervision of the performance of parking tax collection. This supervision was carried out because many taxpayers did not pay taxes owed as they should, were late in paying taxes, and manipulated the turnover they receive. (Ardeshiri et al., 2021). Therefore, a data management and reporting application which can display financial transaction reports in total to support the transparency of tax payments was needed. In order to increase regional income from the tax sector and prevent tax leakage, Regional Revenue Agency (Bapenda) Bekasi City has collaborated with BJB Bank to install an online system for regional taxpayer transactions in the form of a Tapping Box tool. The installation of the Tapping Box is regulated in Bekasi Mayor Regulation Number 132 of 2019 concerning Collection and Management of Regional Taxes through Online System Transactions. Tapping Box is a machine or transaction recording device that can record or capture all transaction data that occurs, then sends it through the Global System for Mobile (GSM) network to Bapenda's server. This tool is functioned to record taxpayer transaction data, so it avoids fictitious internal reports as it can find out real income. Meanwhile, for local governments, this tool is useful for transparency, accountability, effectiveness and efficiency in tax collection. Thus, through the Tapping Box system, it is expected that this is able to increase the income of Bekasi Regency (Atmaja, 2019).

The results of research conducted by (Fauzi, 2019) from The University of Lampung (2019) shows that the use of the Tapping Box in an effort to overcome the Crime of Regional Tax Corruption is an electronic monitoring system for regional tax collection (E-Billing) utilizing modern technology, namely the Tapping Box and the government is using more efforts not to be taxed on taxpayers who commit fraud. local tax corruption. Another study conducted by the use of the Tapping Box can lead to leakage of restaurant taxes, especially if the restaurant pays taxes, namely restaurant entrepreneurs. During the use of this tool in 2019, there was an increase in restaurant 
Modernization of Administration of Parking Tax Collection With Tapping Box as a Supervision and Compliance Function of Regional Taxpayers in Bekasi City

Hidayati, Andayani, Kumala, Subagiyo, Arimbhi

tax revenues compared to 2018 so that its implementation had a positive impact on increasing restaurant tax results in Bandar Lampung City.

Based on the description above, the author is interested in discussing and describing it in a paper entitled "Modernizing of Administration of Parking Tax Collection with Tapping Boxes as a Supervision and Compliance Function of Regional Taxpayers in Bekasi City." Last, the authors provided limitations on what will be studied further. As for what is discussed in this study was regarding to the parking tax supervision using Tapping Boxes in an effort to increase regional taxes of Bekasi city, as well as the obstacles and efforts made by the Bekasi City Regional Revenue Agency. Moreover, the purpose of this study was to find out and analyze parking tax supervision using the Tapping Box along with the obstacles and efforts in parking tax supervision using the Tapping Box.

\section{METHOD}

\section{Research Approach and Type}

The research approach used in this study was a qualitative approach and the type of research was descriptive. This was to facilitate an objective description of parking tax supervision using the Tapping Box, as well as the obstacles and efforts made by the Bekasi City Regional Revenue Agency in Parking Tax Supervision by using the Tapping Box. As a result, it was expected to increase the parking tax revenue at the Bekasi City Regional Revenue Agency.

\section{Data Collection Technique}

Data collection techniques are the most strategic steps in research as the main purpose of research is to obtain data (Sugiyono, 2017:224). The data collection techniques used in this study were interviews, observation and documentation. The data collection techniques based on the way to obtain in this research were primary data and secondary data. The primary data is the data collected directly by research from the first source at the research site, while the secondary data is data collected by organizations that have been legalized or published.

\section{Data Analysis Technique}

The data analysis technique used in this research was descriptive qualitative. The data analysis in qualitative research is a stage consisting of systematic activities to build links of data research in an effort to form meaning that will be used to answer research questions. The data analysis technique used by the author in this study had four criteria, namely: credibility, transferability, dependability, and confirmability.

\section{Research Sites}

This research was conducted at the Bekasi City Regional Revenue Agency office which was located at Jl. IR. H. Juanda No. 100, East Bekasi, Margahayu, Bekasi City, West Java 17530.

\section{RESULT AND DISCUSSION}

The results obtained were based on the results of interviews, observations and documentation. The interviews were conducted with the parties involved in this research such as Regulators, Academics, and Taxpayers. Next, it was also by analyzing the data obtained to determine parking tax supervision using the Tapping Box, along with the obstacles and efforts made by the Bekasi City Regional Revenue Agency. 
Modernization of Administration of Parking Tax Collection With Tapping Box as a Supervision and Compliance Function of Regional Taxpayers in Bekasi City

Hidayati, Andayani, Kumala, Subagiyo, Arimbhi

Discussion is the most important thing in a study. From the results obtained from the research, the authors describe the discussion as follows.

\section{The Supervision of Parking Tax by Using Tapping Box in The Effort of Improving Local Tax in Bekasi City}

Supervision is the process of determining performance measures and taking actions that can support the achievement of the expected results in accordance with the predetermined performance. Tax Supervision by using this Tapping Box is regulated in Bekasi City Mayor Regulation Number 132 of 2019 concerning Collection and Management of Regional Taxes through Online System Transactions. In this theory, there are three indicators that must be analyzed, namely indicators of increasing discipline, indicators of achieving targets for carrying out tasks, and indicators of reducing leakage.

\section{a) Improvement of Discipline}

Tax supervision is important to improve taxpayers' discipline in reporting and paying taxes. By installing this Tapping Box, it is expected to increase the discipline of Parking Taxpayers in reporting turnover and paying taxes. After the installation of this Tapping Box, every 1x24 hours or every 12.00 a.m., the taxpayers are required to send and report transaction data originating from the Tapping Box to the Regional Revenue Agency using the Global System for Mobile (GSM) network. Then, from the data sent by the taxpayer, it will be represented in the form of a dashboard interface and the Bapenda tax office can monitor whether the tax paid by the taxpayer is correct or not. The following is the data on the number of parking tax payers who reported and paid both 'on time' and 'not on time' in 2019.

Table 1. Number of Parking Taxpayers Who Reported and Payed 'On Time' and

'Not On Time' in 2019

\begin{tabular}{cc}
\hline Information & Number of Taxpayers \\
\hline On time & 2913 \\
\hline Not on time & 147 \\
\hline
\end{tabular}

Source: Bekasi City Regional Revenue Agency

Based on the table above, it can be seen that there are 2,913 taxpayers who report and paid taxes on time, while those who were not on time in reporting and paying taxes were 147 taxpayers. From these data, it can be concluded that the level of discipline of taxpayers was quite good and only $4.8 \%$ left who have not been disciplined in reporting and paying their taxes.

\section{b) Less Leakage}

In reporting and paying parking taxes, there were still some taxpayers who did not pay taxes owed as they should, were late in paying taxes, and manipulated the turnover received, causing tax leakage. This is due to the lack of supervision of the performance of tax collection. The purpose of installing an online system in the form of a Tapping Box is to prevent fraud, so that local tax revenues are maximized. This tool is functioned to record all taxpayer transactions. Thus, it was expected to avoid fictitious internal reports, because from this Tapping Box, the real income can be known. 
Modernization of Administration of Parking Tax Collection With Tapping Box as a Supervision and Compliance Function of Regional Taxpayers in Bekasi City

Hidayati, Andayani, Kumala, Subagiyo, Arimbhi

Figure 1. Flow of Parking Tax Collection by Using Tapping Box

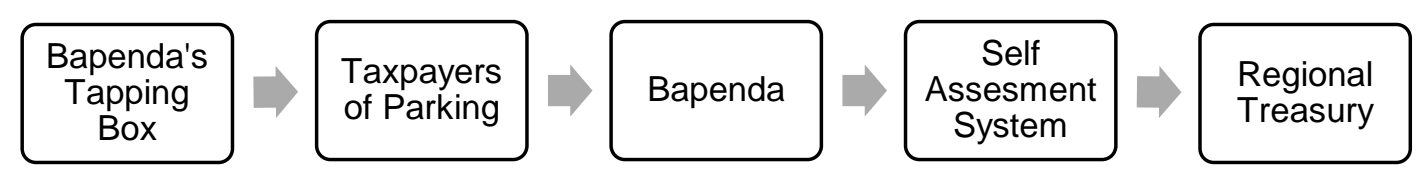

Source : The results of the Researcher's Interview with the Supervision Section of the Bekasi City Regional Revenue Agency

The Regional Revenue Agency cooperates with BJB Bank in the installation of the Tapping Box system at the parking tax payer's place of business. Previously, parking taxpayers had received a circular letter from Bapenda for the installation of the Tapping Box. After the installation of the tool, all transactions for parking taxpayers will be recorded by the Tapping Box machine and every 1x24 hours the taxpayer must send or report the data recorded by the Tapping Box to the Regional Revenue Agency using the GSM network. Every month, the taxpayer pays parking tax in accordance with the existing rates in the Bekasi Regional Regulation Number 03 of 2010 by means of a Self-Assessment System. Here, the Tapping Box is not a tax determination tool, but a tool to monitor how far transactions are made by parking taxpayers. From here, the Bekasi City Regional Revenue Agency can check whether the amount of tax paid by the taxpayer is appropriate or not. If the taxpayers intentionally misuse the Tapping Box, they will receive an appeal and sanctions. Based on the Tapping Box flow above, it is certain that there will be no tax leakage until the money enters the regional treasury. Thus, through the Tapping Box system, it is expected to be able to increase the income of the City of Bekasi.

Regarding the income after the installation of the Tapping Box, based on Table 2 regarding the Target and Realization of Parking Tax Revenue, it can be seen that the realization of parking tax receipts after the installation of the Tapping Box has increased to Rp 10.740.424.485. If the installation of this Tapping Box is further maximized, the increase in parking tax revenue will be maximum.

\section{c) Achievement of Duties' Goal}

The Bekasi City Regional Revenue Agency is less optimal in carrying out its duties to install the Tapping Box. Based on data on the realization of the installation of the Tapping Box, the number of parking taxpayers was 261 taxpayers, but only 51 tools had been installed. This was because there were still several obstacles, including many taxpayers who have not used cash register payments or digital-based cash registers, taxpayers did not provide access to the installation of Tapping Boxes and the impact of the Covid-19 outbreak. However, Bapenda has attempted to conduct socialization or approach to taxpayers directly or through printed media or radio. For parking taxpayers who have not installed the Tapping Box, they are still on a waiting list, which will definitely be installed in the future.

\section{Obstacles that Occurred in Parking Tax Supervision by Using Tapping Boxes in An Effort to Increase Bekasi City Taxes}

In the implementation of parking tax supervision activities by using the Tapping Box, several obstacles are often found. By doing more in-depth interviews on the parties concerned and that plays a role in the implementation of the supervision tax, researchers found some obstacles faced by Revenue Agency of City of Bekasi in the supervision of the parking tax by using Tapping Box. The obstacles occurred which making tax control activities using the Tapping Box difficult were as follows. 
Modernization of Administration of Parking Tax Collection With Tapping Box as a Supervision and Compliance Function of Regional Taxpayers in Bekasi City

Hidayati, Andayani, Kumala, Subagiyo, Arimbhi

a) Power Out

The power failure caused the Tapping Box machine unconnected, so every transaction would not be detected or recorded.

b) The Tapping Box could be turned off by the Taxpayer himself.

There are several taxpayers who deliberately turn off the Tapping Box tool, so the transactions that occurred were not detected. Therefore, it could minimize the taxes paid.

c) There were still some taxpayers who have not used the Cash Register or digital-based-cash register

Tapping Box can only be installed on taxpayers who have used the Cash Register.

d) The installation of tools has not been evenly distributed due to being constrained by Covid19.

The government's policies regarding social distancing and Large-Scale Social Restrictions (PSBB) have made it difficult for officers to meet taxpayers. In addition, several places of business were forced to close due to the government's policy regarding the handling of COVID-19.

\section{Efforts Made in Overcoming Obstacles that Occurred in Parking Tax Supervision by Using Tapping Boxes in An Effort to Increase Bekasi City Taxes}

In the implementation of Tax Supervision activities by using the Tapping Box, surely, there are several efforts made to overcome the obstacles that arose in the Tax Supervision activities. Based on the results of the study, the efforts made by the Bekasi City Regional Revenue Agency were as follows.

a) A sim card and battery should be provided.

When the power is out, there is still battery power and a sim card to store transactions that occur during a power outage.

b) The taxpayers who turned off the Tapping Box tool will be detected through the dashboard in Bapenda.

Bapenda will directly contact the taxpayers who intentionally turned off the Tapping Box tool and urges them to turn the Tapping Box back on. If the taxpayer makes the same mistake, they will receive administrative sanctions listed in the Bekasi Mayor Regulation Number 132 of 2019.

c) Bapenda will prepare tools outside the Tapping Box

This tool will be installed specifically for taxpayers who have not used the cash register so that in the future tax supervision will be maximized.

d) The taxpayers were still on the waiting list.

There are still some taxpayers who are still on the waiting list, which will all be installed in the future. 


\section{CONCLUSION}

Based on the results of the research, discussion, and interpretation that have been described previously, and with reference to the supervisory theory according to Arifin Abdul Rachman (2001: 23) and the results of previous studies, the conclusions can be drawn as follows.

1) Tax Supervision by using the Tapping Box carried out by the Bekasi City Regional Revenue Agency as a whole has not been running well. Here, based on the results of the study indicated that the implementation of tax control using the Tapping Box has not reached the predetermined target. The realization of parking tax receipts after the installation of the Tapping Box did increase by $10 \mathrm{M}$, but this has not yet reached the predetermined target. This was because the installation of the Tapping Box tool has not been evenly distributed and there were still many taxpayers who have not used a cash register for payment or a digital-based cash register. Thus, the Tapping Box could not be installed. If the installation of the Tapping Box was carried out evenly, regional income from parking taxes will increase more.

2) The obstacles in the implementation of parking tax supervision by using the Tapping Box, namely power outages, the reluctance of taxpayers in implementing the Tapping Box installation, there were still many taxpayers who have not used cash register payments or digital-based-cash registers and the impact of Covid-19 which made it difficult for officers to meet the taxpayers.

3) The efforts made by the Bekasi City Regional Revenue Agency in overcoming tax control obstacles by using the Tapping Box, namely the Regional Revenue Agency should prepare a sim card and battery that can accommodate transactions that occur during a power outage. Then, the Regional Revenue Agency should approach and socialize to taxpayers to provide understanding to them about the purpose and benefits of the Tapping Box. Moreover, the Agency should ensure that entrepreneurs will not be harmed, so the taxpayers want to install the Tapping Box tool. Regarding to the parking taxpayers who have not used the cash register, the Bekasi City Regional Revenue Agency will prepare a special tool outside the Tapping Box for taxpayers, so in the future tax supervision will be maximized. Next the Bekasi City Regional Revenue Agency also urges each Regional Technical Implementation Unit (UPTD) to carry out regular monitoring and evaluation to ensure that the tool functions properly. Moreover, they should take an inventory of existing problems/obstacles and report the results of the monitoring and evaluation to the head of the Regional Revenue Agency every Friday for every week.

Based on the discussion of the conclusions that have been submitted, the authors provide the following suggestions:

1) Related to the limited human resources in the installation of the Tapping Box tool, the Bekasi City Regional Revenue Agency should increase the number of Tapping Box installation officers. It is because the tapping box installation officer is not proportional to the number of parking taxpayers registered in the city of Bekasi. Such lack of human resources also causes the implementation of socialization regarding the benefits and importance of using the Tapping Box has not been maximized.

2) For taxpayers who do not want their business to be installed with a Tapping Box and those who have been installed but they misuse the Tapping Box, the Bekasi City Regional Revenue Agency should provide strict sanctions in the form of closing the business for entrepreneurs who do 
Modernization of Administration of Parking Tax Collection With Tapping Box as a Supervision and Compliance Function of Regional Taxpayers in Bekasi City

Hidayati, Andayani, Kumala, Subagiyo, Arimbhi

not obey, giving fines, or sanctions in the form of confinement by renewing existing Regulation of Mayor (Perwal).

3) For taxpayers who have not used cash register payments or digital-based-cash registers, the Bekasi City Regional Revenue Agency should immediately launch a special tool that has the same function as the Tapping Box. It is for a tax control and increasing local tax revenue.

\section{REFERENCE}

Ardeshiri, A., Safarighouzhdi, F., \& Hossein Rashidi, T. (2021). Measuring willingness to pay for shared parking. Transportation Research Part A: Policy and Practice, 152, 186-202. https://doi.org/10.1016/j.tra.2021.08.014

Atmaja, E. S. (2019). Tapping Box Wajib Pajak Kabupaten Bekasi. Jurnal Indonesia Baru. https://jurnalindonesiabaru.com/2019/12/17/tapping-box-wajib-pajak-kabupaten-bekasiakan-di-pasang-560-se-wilayah-bekasi/

Bird, R. M., \& Zolt, E. M. (2005). The limited role of the personal income tax in developing countries. Journal of Asian Economics, 16(6), 928-946. https://doi.org/10.1016/j.asieco.2005.09.001

Fauzi, D. R. (2019). Penggunaan Tapping Box dalam Upaya Penanggulangan Tindak Pidana Korupsi Pajak Daerah (Studi Di Kota Bandar Lampung) [Universitas Lampung]. https:// docplayer.info/187751410-Penggunaan-tapping-box-dalam-upaya-penanggulangantindak-pidana-korupsi-pajak-daerah-studi-di-kota-bandar-lampung-skripsi-oleh-desta-riskafauzi.html

Feitelson, E., \& Rotem, O. (2004). The case for taxing surface parking. Transportation Research Part D: Transport and Environment, 9(4), 319-333. https://doi.org/10.1016/j.trd.2004.04.002

Gragera, A., Hybel, J., Madsen, E., \& Mulalic, I. (2021). A model for estimation of the demand for on-street parking. Economics of Transportation, 28, 100231. https://doi.org/10.1016/j.ecotra.2021.100231

Mardiasmo. (2016). Perpajakan (Mardiasmo (ed.); III). Andi. http:/ /www.library.usd.ac.id/web/index.php?pilih=search\&p $=1 \& q=0000133697 \& g o=$ Det ail

Ostermeijer, F., Koster, H., Nunes, L., \& van Ommeren, J. (2021). Citywide parking policy and traffic: Evidence from Amsterdam. Journal of Urban Economics, 103418. https://doi.org/10.1016/j.jue.2021.103418

Pandiangan, L. (2008). Modernisasi \& reformasi pelayanan perpajakan berdasarkan UU terbaru (L. Pandiangan (ed.); I). PT Elex Media Komputindo. https:/ /opac.perpusnas.go.id/DetailOpac.aspx?id=491531

Parmar, J., Das, P., \& Dave, S. M. (2021). A machine learning approach for modelling parking duration in urban land-use. Physica A: Statistical Mechanics and Its Applications, 572, 125873. https://doi.org/10.1016/j.physa.2021.125873

Rahayu, S. K. (2010). Perpajakan Indonesia : Konsep dan Aspek Formal (S. K. Rahayu (ed.); I). Graha Ilmu. http://inlislite.uin-suska.ac.id/opac/detail-opac?id=19839

Rosdiana, H., \& Irianto, E. S. (2012). Pengantar Ilmu Pajak: Kebijakan dan Implementasi di Indonesia (H. Rosdiana (ed.)). CV Rajawali. http://lib.ui.ac.id/detail?id=20339121 
Modernization of Administration of Parking Tax Collection With Tapping Box as a Supervision and Compliance Function of Regional Taxpayers in Bekasi City

Hidayati, Andayani, Kumala, Subagiyo, Arimbhi

Sadhani, D. (2012). Pajak Menuju Good Governance Melalui Modernisasi (D. Sadhani (ed.); II). PT Rineka Cipta.

Tscharaktschiew, S., \& Reimann, F. (2021). On employer-paid parking and parking (cash-out) policy: A formal synthesis of different perspectives. Transport Policy, 110, 499-516. https://doi.org/10.1016/j.tranpol.2021.07.002 